\title{
A review of research on crime displacement theory
}

\author{
Ching Eng Leong \\ Faculty of Social Sciences, University Sains Malaysia, Penang, Malaysia
}

\section{Email address:}

ELChing.EngLeong@honeywell.com

\section{To cite this article:}

Ching Eng Leong. A Review of Research on Crime Displacement Theory. International Journal of Business and Economics Research. Special Issue: Supply Chain Management: Its Theory and Applications. Vol. 3, No. 6-1, 2014, pp. 22-30. doi: 10.11648/j.ijber.s.2014030601.14

\begin{abstract}
Reppetto (1976) published crime displacement theory in Journal of Research in Crime and Delinquency and put forward his theoretical underpinnings for the future analysis of crime displacement phenomenon and outlined five types of crime displacement such as: 1 . Temporal - Committing the intended crime at a different time; 2. Tactical - Committing the intended crime in a different way; 3 . Target - Committing the intended crime type on a different target; 4. Spatial - Committing the intended crime type to the same target in a different place; 5. Functional - Committing a different type of crime. Research on crime displacement began to be carried out in a more systematic manner during the 1990s. There was a significant step forward when research in 1990 and 1993 specifically studied displacement and found it to be much less of problem than had generally been supposed. Crime displacement occurred where it was most likely to be similar targets or to similar and adjacent areas. Although the findings were greatly positive, there was and not surprisingly, variation between different crimes. Research has consistently found that crime displacement is the exception rather than the rule and that diffusion of benefits is just as likely and sometimes more likely to occur. Research also shows that crime displacement is unlikely in the aftermath of broader community development programs. In cases where some displacement occurs it tends to be less than the gains achieved by the response and found that crime displacement and diffusion are equally likely to occur. The theory of crime displacement is related to rational choice theory and there are three assumptions regarding the potential perpetrator and the target. The theory of crime displacement does not explain the reason of perpetrators committing a certain crime or why some crimes are more attractive to them than others. Crime displacement can occur in different ways or methods. An often-stated opinion about crime displacement is the theory, its practical usages, that it can induce a sense of disbelief towards crime prevention initiatives.
\end{abstract}

Keywords: Crime Displacement, Types of Crime Displacement, Rational Choice Theory, Perpetrators, Criminal Patterns

\section{Introduction}

Crime can be distinguished into 3 elements namely motivated perpetrator, transported goods and lack of guardian (Sherman, Gartin \& Buerger, 1989). These elements are known to be present in all types of crime. The relationship among the 3 elements is very complex and changes in one of the element may prevent the crime from happening. There are a few different views or explanation related to the driving force and the motivation that causes the crime to occur. Crime can be linked to social process, human behavior and other traits or factors where the pattern of crime can be of temporary and ecological factors (Parker, 1995). The pattern of crime was expressed in a series of papers published by Felson and Clark (1998). The volume and distribution of predatory crime against a person or crime which an offender attempted to steal an object are closely related to the interaction of the 3 variables that was typical crime element found in America as illustrated in Figure1. The availability of suitable target for the predator; the absence of guardian and the presence of motivated offenders most likely causing the crime to take place (Teresa, 1999).

The decision to commit crime is structured by analysis of the type of crime, the time and place of crime, and the target of crime. Criminal tends to move away from committing the crime if they perceived it as difficult or potentially dangerous for them to commit (Garry \& Don, 2001). Evidence showed that jurisdiction with relatively low incarceration rates also experienced the highest crime rate (Rengert, 1989). Crime can be avoided if potential targets are guarded securely, means or opportunities to commit are controlled and potential targets are monitored closely. This will convince potential criminals to abstain from committing the crime, delay their action or even avoid committing the crime. 


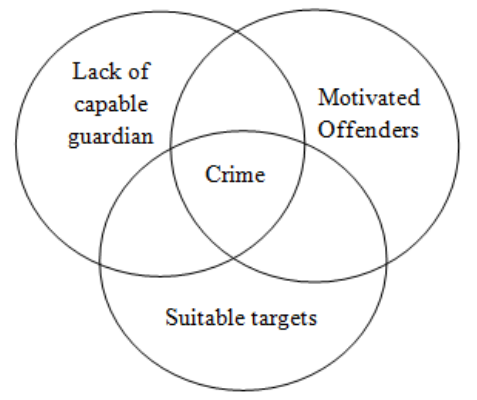

Figure 1. Routine Activities Theory: The Interaction of Three Factors

Source: Teresa, LaGrange (1999). The Impact of Neighborhoods, Schools, and Malls on the Spatial Distribution of Property Damage, Journal of Research in Crime and Delinquency, 36, 393 - 422.

\section{The Background of Crime Displacement Theory}

Reppetto (1976) published crime displacement theory in Journal of Research in Crime and Delinquency and put forward his theoretical underpinnings for the future analysis of crime displacement phenomenon and outlined five types of crime displacement such as:

i Temporal - Committing the intended crime at a different time

ii Tactical - Committing the intended crime in a different way

iii Target - Committing the intended crime type on a different target

iv Spatial - Committing the intended crime type to the same target in a different place

$\mathrm{v}$ Functional - Committing a different type of crime

Ronald V. Clarke is one of the earliest criminology professor analyzing crime theory by defining crime is being displaced known as crime displacement theory. He is the Dean as well as a Professor at the School of Criminal Justice at Rutgers University in New Jersey since 1987. Clarke (1998) argued that crimes are displaced by removing opportunity for crime or by changing the situation of the crime and when this occurs it does not actually prevent crime but merely moves or shift the crime to another location. There are five main ways in which Clarke (1998) suggested that crime is being moved around:

i Geographical displacement - crime can be moved from one location to another which is identified

ii Temporal displacement - crime can be moved from one time to another

iii Target displacement - crime can be directed away from one target to another

iv Tactical displacement - one method of committing crime can be substituted for another

$\mathrm{v}$ Crime type displacement - one kind of crime can be substituted for another

Clark (1998) suggested that crime can be reduced by the following:

a Opportunity - reducing measures by analyzing at the specific crimes;

b Design the place which makes crime difficult to occur or;

c Make the crime itself more difficult and risky for the offenders.

\section{Understanding and Discussion on Crime Displacement Theory}

The theory of crime displacement is related to rational choice theory and there are three assumptions regarding the potential perpetrator and the target (Lab, 2000). Lab argued that crime displacement assumes that crime is inelastic; the perpetrator has the flexibility relative to time, place, method and type of crime; and the existence of unlimited alternatives targets available. Professional criminal are more inelastic while opportunist criminal are more elastic (Hesseling, 1994). In reality, perpetrators are normally limited in their mobility, adaptability and flexibility, relative to a particular crime, place, time, method and the number of targets is limited in one way or another (Hesseling, 1994). The theory of crime displacement does not explain the reason of perpetrators committing a certain crime or why some crimes are more attractive to them than others. Furthermore, it does not explain the perpetrators' perceptions and reactions to changes in opportunities (Hesseling, 1994). The key element in all crime is the role that opportunity plays, for example, if there is no opportunity there is no crime (Felson \& Clarke, 1998). Crime displacement can occur in different ways or methods. An often-stated opinion about crime displacement is the theory, its practical usages, that it can induce a sense of disbelief towards crime prevention initiatives (Town, 2001). One problem with the crime displacement theory is that it is accepted because it instinctively appeals to people's common sense. Town (2001) illuminates this problem as:

- Criminals prevented or stopped them in one location then they just find another.

- Common sense is a valuable commodity, but it has its limitations and changes with time.

Total displacement and partial displacement are different and the usage of common sense is attracted to the idea of total displacement. The theory of crime displacement states that rational thinking perpetrators with crime mobility will alter their criminal behavior in response to crime prevention efforts (Lab, 2000). The objective is to reduce crime opportunities, which will lead to a change in all potential theft situations; therefore, crime displacement is a valid theory.

Crime displacement is one probable explanation the criminal pattern changes in a certain system. A practical and common belief about crime displacement is that if perpetrators have the ability, mobility and flexibility to exploit the weakest link in the chain, they will do so to commit the crime (Ekwall \& Lumsden, 2007). It is the perpetrators' ability to organize a successful theft, and their relationship relative to the actors, within the network that are 
the fundamental variables to categorize perpetrators. The crime preventive measures are of great importance to force a change in the perpetrators' decision process. A simplification of the benefit with a crime can be illustrated with the target that the perpetrators want.

Crime displacement theory is related to situational crime prevention based on the theoretical premise of rational choice (Cornish \& Clarke, 1986). An individual or criminal makes a decision as to whether or not to commit an offence based on a range of inputs. These include the effort involved, the potential payoff, the degrees' of peer support for the action, the risk of apprehension and punishment, and individual needs. The theory does not state that a perpetrator will commit a crime for every opportunity they encounter. Rather, the potential perpetrator makes a calculated decision about the opportunity to commit a crime (Lab, 2000). In short, a perpetrator acts according to the rational choice theory, seeking to maximize its utility with regards to time and resources available (Bodman \& Maultby, 1997). Situational crime prevention addresses the symptoms but not the cause of the crime. This can lead to an excessive trust in technology (Crawford, 1998). Both of these criticisms are valid for the usage of situational crime prevention to hinder theft. Basically, this is achieved by applying the following four prevention principles of; i) increased perceived efforts; ii) increased perceived risks; iii) reducing anticipated rewards and; iv) inducing guilt or shame (Clarke, 1992; Clarke \& Homel, 1997).

Deeper understanding is required on the motives and modus operandi of target groups of offenders which provides a way of dealing with the limitations of the statistical search for crime displacement (Barr \& Pease, 1990). It may not always be possible to interview offenders, but in some cases insights on motivation and methods can be provided by closer analysis of patterns of offenders. In this case, Clarke (1992) has shown significant variances among automobiles in their risks for different forms of theft, which reflect the motives of offenders. Cornish and Clarke (1987) found that new cars are most at risk of being striped in the United States during the mid-1980s where mostly European models with good audio equipment; joyriding cars were American made muscle car and those higher-prices luxury vehicles are for resale and the target of vehicles are not difficult to understand in terms of the motives of offenders. Under the dispositional assumptions of traditional criminological theory, situational variables merely determine the time and place of offending. As such, offender may target for smaller criminal rewards of crime if the alternatives are not feasible. Some offenders are so driven by needs or desires that they have to maintain a certain level of offending regardless of the cost. For many, the elimination of easy opportunities for crime may actually encourage them to explore other criminal alternatives. On the other hand, since crime is the product of purposive and sometimes inventive minds, displacement to other categories of offense or other areas are expected.

There are many examples of displacement reported. A property marking program in Ottawa, Canada may have displaced burglaries from the homes of participants to those of non-participants (Gabor, 1990). Evidence has begun to accumulate of the successful application of situational measures with few displacement costs in accordance with the development of crime displacement analyses. Crime displacement has been studied in specific geographical areas (example, shopping centers, parking lots, housing estates and neighborhoods). Crime prevention efforts do not aim to alter the root causes of crime and the offenders who are deflected simply shift to other targets or places, severely limiting the net reduction in crime rate. Many authors viewed crime displacement as the result of the implementation of effective measures against crime (Gabor, 1990; Ekwall, 2009; Cook \& Mac Donald, 2010; Klaus, 2011). Thus, Gabor (1990) defined crime displacement as a change in offender behavior, along with illegitimate means, which is designed to get away with either specific preventive measures or more general conditions unfavorable to the offender's usual mode of operating. For example, a burglar may move to a different neighborhood, employ new tactics, and offend at a different time of day. Only a few authors acknowledged and suggested that given the extent to which different forms of displacement operate at the same time, it may be impossible to confirm empirically the existence or magnitude of displacement (Barr \& Pease, 1992; Ekblom, 1989). Studies of crime displacement tend to assume rational decision making from the offenders. Offenders are most likely to displace when other crime targets are familiar to them (Cornish \& Clarke, 1986; Eck, 1993).

Crime displacement has been studied empirically in two different ways that is by conducting ethnographic studies of offenders' motives and offenders' decision-making processes whether to commit the crime or likewise; and by evaluating the impact of programs to reduce crime. Most studies of crime displacement take the latter approach, evaluating the amount of displacement resulting from a crime prevention measure by examining crime rates in adjacent areas or for other offenses. If researchers observed an increase in crime rates, they typically assume that displacement has occurred as the result of the crime prevention measures effectively implemented. There are possibilities that other factors independent to the prevention measures such as changes in the offender population, the opportunity structure, or the overall trend of crime rates at the area. Only a few authors have stressed these other factors in their explanations of the displacement effects of crime prevention projects (Hakim \& Rengert 1981; Barron, 1991). If these other factors are disregard by the researchers, the amount of crime being displaced may be overestimated. Crime displacement is highly complex and the amount of displacement may depend both upon whether offenders resort to any combination of alternative targets, times, places, methods, and offenses, and whether these alternatives are familiar to the offender. In addition, researchers may mistakenly assume that a crime prevention effort may cause an increase in crime rates, when this causal relationship may in fact be spurious. Thus, crime displacement is difficult to predict and often impossible to 
measure but it is safe to assume that most preventive measures may potentially result in crime displacement.

It is very difficult to change peoples' habit or routine in crime prevention. Cornish and Clarke (2003) developed situational crime prevention techniques which can be grouped into five categories such as:

i Increasing the efforts,

ii Increasing the risk,

iii Reducing the rewards,

iv Reducing the provocations, and

$\mathrm{v}$ Removing the excuses

Increasing the efforts techniques can be carried out by hardening the targets such as implementation of access control points, screening of exits, and other tools and weapon used to decrease the crime. Reduction of risk by extending the guardianship such as neighborhood watch, assisting natural surveillance, and strengthening formal surveillance can make crime more difficult to happen. When the opportunity for burglary is blocked, burglar moves to another neighborhood, but either the frequency of burglary is less than before or the new neighborhood is less vulnerable than before (Clarke \& Weisburd, 1994). Crime prevention efforts are supported by the argument that even the displacement is mild; it spreads the burden of crime more equitable across the community or replaces more serious with less (Barr \& Pease, 1990). Eck (1993) summarized thirty three crime prevention interventions and displacement in those studies. In three of these studies evidence of much displacement was found; in twelve of them there were some displacement; and in eighteen of them there was no displacement (Eck, 1993). Crime displacement was not found in 22 studies after reviewing 55 studies and it was never 100 percent in the remaining studies (Gabor, 1990; Eck, 1993; Hesseling, 1994). Dingle (2005) summarizes the crime displacement that if given a choice, criminals will choose the easiest route, and will choose to commit crimes that provide the least probability of getting caught.

\section{Strength of Crime Displacement Theory}

The key to such an argument is that crime prevention can be quite successful, even when displacement is both inevitable and complete. While such a statement seems contrary to reason (given that no overall reduction in crime is produced), there are still beneficial; if sometimes temporary and effects to be gained from the prevention of crime. In fact, it is important to recognize that only effective means of crime prevention can be capable of producing displacement in the first place (Gabor, 1981, 1990; Barr \& Pease, 1990). But the advantages of displacement go well beyond this simple, almost tautological, analogy. They range from the selfish to the selfless and extend benefits to the individual, the community and society as a whole. At its most basic level, displacement is of extreme value to those who have avoided victimization. Both Sherman (1990), Barr and Pease (1990) have commented upon this 'NIMBY' (not in my backyard) approach to crime prevention, which is primarily concerned with preventing crime against a specific target; regardless of its effects elsewhere. A change in the patterns of crime will always be considered beneficial for most cases, provided that the nature of change places the threat of victimization further from their own lives. The avoidance of crime can also be much more widespread, benefiting almost everyone, for at least a short time after the introduction of a crime control measure.

\section{The Weakness of Crime Displacement Theory}

There may be some weaknesses in crime displacement theory. The first holds that displacement is essentially unfavorable, since the prevention strategies that cause it gives no overall decrease in crime (Hakim \& Rengert, 1981). The second element concerns the belief that displacement is inevitable. The negative aspects of displacement, combined with its inevitability, are used to show that social or corrective prevention would be more effective (albeit more costly and difficult) alternatives to the use of situational methods (Reppetto, 1976). An intensive effort has been made to show that displacement is not the inescapable result of any crime control program (Cornish \& Clarke, 1986; Miethe, 1991). A primary reason for weakness in the available research is that displacement, like crime itself, is very difficult to measure. Even if no displacement is found in a given study or research, it could have occurred in a direction that was not examined (Cornish \& Clarke, 1986), or the displaced crime could easily be concealed within the overall crime rate (Mayhew, 1988).

\section{Research Conducted on Crime Displacement}

Research on crime displacement began to be carried out in a more systematic manner during the 1990s. There was a significant step forward when research in Canada (Gabor, 1990) and the United States (Eck, 1993) specifically studied displacement and found it to be much less of problem than had generally been supposed. As suggest by Eck (1993), displacement occurred where it was most likely to be to similar targets or to similar and adjacent areas. Although the findings were greatly positive, there was, not surprisingly, variation between different crimes. Drug dealing, for example, had been found to be susceptible to displacement (Rengert, 1990; Sherman, 1990; Caulkins, 1992; Eck 1993), which echoed the views of Barr and Pease (1990) on perpetrator displacement.

In 1994, the Ministry of Justice in Holland has tasked Professor Rene B.P. Hesseling to conduct research systematically by analyzing all the available literatures on crime prevention measures specifically looked for evidence 
of crime displacement. This huge task took fourteen months and involved reviewing fifty-five published articles related to crime displacement. The summary stated that crime displacement is a possible, but not inevitable consequence of crime prevention (Hesseling, 1994). Further, if crime displacement does occur, then it will be limited in size and scope. This conclusion is supported by other review studies on this topic (Clarke, 1999). It is believed that criminologists have generally shown little interest in crime displacement prevention. This neglect stems from what the regards as two mistakes of modern criminology. The first problem of explaining crime has been confused with the problem of explaining the criminal and the second related mistake is to confuse the problem of controlling crime with that of dealing with the criminal (Moss \&Pease, 1999).

In 1999, evaluations were carried out by the Building Research Establishment (BRE) United Kingdom (Pascoe, 1999), Gwent Police in South Wales (Brown, 1999) and by the Applied Criminology Group, University of Huddersfield (Armitage, 1999). The results of all three studies were very positive and the issue of displacement was discussed to varying degrees. Although not specifically focused on displacement, the BRE report, commenting on a large burglary reduction in one scheme, stated that it has not displaced the crime to the neighbors and the report found no evidence of displacement from prevented burglary into other crime (Brown, 1999). As regards to displacement, the evidence from the broad based analysis suggested that there is a diffusion of benefits, as opposed to displacement of crime. This is particularly evident on some estates (Armitage, 1999).

Crime displacement inevitably occurs with the implementation of policing efforts are largely based on unfounded suppositions rather than empirical facts as discussed by (Eck, 1993; Hesseling, 1994; Hill \& Pease, 2001). Research also shows that crime displacement is unlikely in the aftermath of broader community development programs (Roman, Cahill, Coggeshall, Lagerson, \& Courtney, 2005; McLennan \& Whitworth, 2008) and more focused policing initiatives that centered on hot spots crime area (Braga, 1999; Weisburd, 2006; Braga, 2007). An evaluation of the Weed and Seed program in Miami, Florida, found that spatial diffusion of benefits occurred more commonly than spatial displacement (Roman, 2005).

Crime displacement inevitably occurs in the aftermath of problem-led policing efforts is largely based on unsupported suppositions rather than empirical facts. Research has consistently found that crime displacement is the exception rather than the rule and that diffusion of benefits is just as likely and sometimes more likely to occur (Eck, 1993; Hesseling, 1994; Hill \& Pease, 2001). In cases where some displacement occurs it tends to be less than the gains achieved by the response and found that crime displacement and diffusion are equally likely to occur (Guerette \& Bowers, 2008). An analysis of a subsample of 13 studies, which allowed for the assessment of the prevention project's overall outcomes while accounting for spatial displacement and diffusion effects, found that when spatial displacement did occur, it tended to be less than the response effect. In short, the responses were still beneficial on average (Guerette, Rob \& Kate, 2009).

An evaluation of the New Deal for Communities (NDC) program in the United Kingdom discovered that, among 383 buffer zones, spatial diffusion of benefits was observed in 23 percent of the zones, while spatial crime displacement was observed in only 2 percent of the zones. The remaining 75 percent showed no signs of displacement or diffusion. Also, across the buffer zones offense diffusion was more common than offense displacement (McLennan \& Whitworth, 2008). A review of crime hot spots policing of the five studies that examined displacement and diffusion effects found that none of the review reported any substantial immediate spatial displacement of crime into areas surrounding the targeted locations while four studies found possible diffusion effects (Braga, 2007). Research conducted to identify the presence of displacement in a problem-oriented policing project was conducted in Lowell, Massachusetts and found no significant crime displacement to the areas immediately surrounding the targeted places (Braga \& Bond, 2008). It should be noted, however, that there may be times when crime displacement is simply undetectable. Offenders may move to other jurisdictions or switch to other crimes from which no data can be obtained. Due of this, the research findings reported above may undercount the true extent of crime displacement effects. Offender's familiarity with locations also provides lower risks to them because they can identify entry and exit points more readily which allow them to approach and leave crime scenes in shorter time. Offenders' spatial familiarity is primarily determined by the known places and the surrounding area that they frequent as part of their normal living routines. This provides minimal effort for offenders in the meantime allowing them to commit crimes easily in their zone. For target and tactical crime displacement, familiarity means offenders are more likely to select similar target and use the same tactics they have used in former crimes. The offender will not engage on targets they are not familiar. Most offenders acquired skill sets from peer groups or other delinquent associations as well as through their direct and indirect experiences of committing crime (Cornish, 1994). The use of existing skill sets is much less likely in the absence of other available crime targets. Highly motivated offenders may expend the effort to acquire new skill sets, but the more common opportunistic offender is less likely to do so. The presence of crime opportunities also determines when and where crime displacement may occur as stipulated in Figure 2. Crime displacement is more likely to happen where there are suitable crime targets. This is contingent upon the offenders' motivation and familiarity with the crime targets and tactics needed to carry out the crime. Responses that occur adjacent to areas that have unprotected crime targets are more likely to experience some level of crime displacement compared to those that do not. 


\begin{tabular}{|l|l|l|}
\hline \multicolumn{1}{|c|}{ Predictors } & Factors & How it relates to displacement \\
\hline Offender Motivation & Addiction & $\begin{array}{l}\text { Likely to displace to other crimes that } \\
\text { facilitate addiction. }\end{array}$ \\
\cline { 2 - 3 } & $\begin{array}{l}\text { High Motivation (career } \\
\text { offenders) }\end{array}$ & $\begin{array}{l}\text { More likely to displace than desist from } \\
\text { crime. More likely to expend the effort to } \\
\text { find new crime opportunities and or learm } \\
\text { new skills. }\end{array}$ \\
\cline { 2 - 3 } & $\begin{array}{l}\text { Low Motivation (opportunistic } \\
\text { offenders) }\end{array}$ & $\begin{array}{l}\text { More likely to desist from crime than } \\
\text { displace. } \\
\text { Less likely to expend the effort to find new } \\
\text { crime opportunities and or learn new skills. }\end{array}$ \\
\cline { 2 - 3 } & $\begin{array}{l}\text { Instrumental (motivated by } \\
\text { money) }\end{array}$ & $\begin{array}{l}\text { More likely to seek out other crime targets } \\
\text { and types that provide similar monetary gain }\end{array}$ \\
\cline { 2 - 3 } & $\begin{array}{l}\text { Expressive (usually violent or } \\
\text { destructive) }\end{array}$ & $\begin{array}{l}\text { Usually highly contextual. Less likely to } \\
\text { displace once situation is altered or } \\
\text { remedied. }\end{array}$ \\
\hline $\begin{array}{l}\text { Offender Familiarity of } \\
\text { other targets, locations or } \\
\text { skill sets }\end{array}$ & High/many & More likely to displace crime behavior. \\
\cline { 2 - 3 } & Low/few & $\begin{array}{l}\text { Less likely to displace or will take longer to } \\
\text { do so. }\end{array}$ \\
\hline Crime Opportunity & Nearby & More likely to displace crime behavior. \\
\cline { 2 - 3 } & Distant & $\begin{array}{l}\text { Less likely to displace or will take longer to } \\
\text { do so. }\end{array}$ \\
\hline
\end{tabular}

Figure 2. Predictors and factors of crime displacement

Source: Cornish, Derek B. (1994). The procedural analysis of offending and its relevance for situational prevention in Crime Prevention Studies, 3, Clarke, R.V. \& Monsey, (Eds.), New York, Criminal Justice Press.

\section{Factors of Crime Displacement}

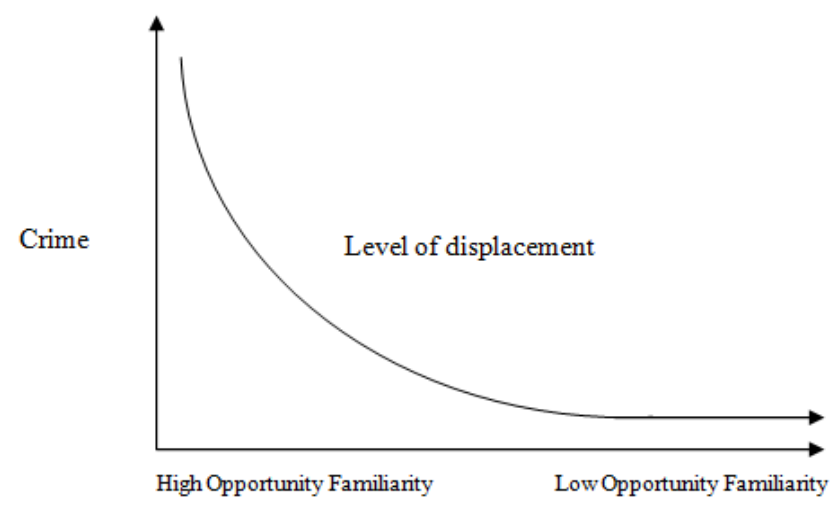

Figure 3. Familiarity Decay and Crime Displacement

Source: Eck, John E. (1993). The Threat of Crime Displacement, Criminal Justice Abstracts, 25, 527 - 546.

Occurrence of displacement is largely determined by three factors; i) offenders motivation, ii) offenders familiarity and; iii) crime opportunity. Likewise, instrumental offenders are more likely to search for other crime targets and types that provide similar monetary gain (Guerette, Stenius \& McGloin, 2005). Offenders are more likely to relocate their behavior to crime targets, places, times, and tactics with which they are most familiar. This means if displacement occurs it is most likely to be close to the original crime location and involve similar targets and tactics. The probability of displacement is greatest close to the original crime location and decreases as the distance from the response area increases as in Figure 3 (Eck, 1993). Offenders are more likely to relocate their behavior to crime targets, places, times, and tactics with the one which they are most familiar (Eck, 1993). Offenders are less likely to offend in unfamiliar locations because it poses greater risk and greater effort to familiarize themselves with new locations. Distance from the original crime location increases the probability of unfamiliarity among offenders.
Crime displacement occurs mainly determined by three aspects such as offender motivation, offender familiarity, and crime opportunity. Offender motivation determines which offenders and types of crimes are likely to be displaced. Offenders driven by drug addiction are more likely to displace their crime behavior to crime types and targets that facilitate their addiction. Opportunistic offenders will continue to be involved in crime after a response because their motivation is greater. Likewise, instrumental offenders (e.g., those motivated by monetary gain) are more likely to seek out other crime targets and types that provide similar monetary gain (Guerette et al., 2005).

Different crimes present different costs, efforts, and rewards as there are many instances when displacing crime behavior is not worthwhile for the offender. Offenders displace their criminal behavior only when the risks and effort of committing new crimes are worth the reward (Cornish \& Clarke, 1986). In other words, opportunities to commit crime are not evenly distributed across time and place. Another aspect to consider is that when crime opportunities are closed down, committing other crimes is not the only way offenders can meet their needs. Blocking crime opportunities can make satisfying individual needs through legitimate activities more appealing. An offender's decision as to whether to displace his crime behavior in the aftermath of a response is shaped by the variety of circumstances found among other crime types, targets, times, tactics, and places (Cornish \& Clarke, 1987). Crime displacements often will not occur if offender knowledge is bounded of knowing the way to commit the crime. This means the offender may not be well versed with the skill or tactic to commit that crime.

\section{Other Theories Related to Crime Displacement Theory}

Three recent theoretical perspectives: 1) rational choice, 2) routine activity theory, 3) crime pattern theory; have influenced the understanding of the importance of place in crime prevention efforts. A rational choice perspective provides the basic rationale for defining place as essential, since it suggests that offenders will select targets and define means to achieve their goals in a manner that can be explained (Cornish \& Clarke, 1986). Some claim that this perspective is to some degree un-testable, while others have demonstrated that it is possible to test various forms of rational choice (Hogarth \& Reder, 1981). Routine activity theory seeks to explain the occurrence of crime events as the confluence of several circumstances (Cohen \& Felson, 1979; Felson, 1994). First, there must be a motivated offender. The explanation of the development of motivated offenders is the goal of offender theories. Second, there must be a desirable target. Third, the target and the offender must be at the same place at the same time. Finally, three other types of controllers: 1) intimate handlers, 2) guardians and; 3) place managers; must be absent or ineffective. For a crime to occur, 
guardian must be absent, ineffective or negligent (Eck, 1994).

Crime pattern theory is particularly important in developing an understanding of crime and place because it combines rational choice and routine activity theory in aid of explaining the distribution of crime across places. The distribution of offenders, targets, handlers, guardians, and managers over time and place will describe crime patterns. Changes in society have increased the number of potential targets while separating them from the people who can protect them (handlers, guardians, and managers). Reasonably rational offenders, while engaging in their routine activities, will note places without guardians and managers and where their handlers are unlikely to show up. Pattern theory explores the interactions of offenders with their physical and social environments that influence offenders' choices of targets. According to crime pattern theory, how targets come to the attention of offenders influences the distribution of crime events over time, space, and among targets (Brantingham \& Brantingham, 1993). This occurs because offenders engage in routine activities. Just like other, non-offending individuals, offenders move among the spheres of home, school, work, shopping, and recreation. As they conduct their normal legitimate activities, they become aware of criminal opportunities. Thus, criminal opportunities that are not near the areas offenders routinely move through are unlikely to come to their attention. A given offender will be aware of only a subset of the possible targets available. Criminal opportunities found at places that come to the attention of offenders have an increased risk of becoming targets (Brantingham \& Brantingham, 1993). While a few offenders may aggressively seek out uncharted areas, most will conduct their searches within the areas they become familiar with through noncriminal activities.

The concept of place is essential to crime pattern theory. Not only are places logically required (an offender must be in a place when an offense is committed), their characteristics influence the likelihood of a crime. Place characteristics highlighted by routine activity theory include the presence and effectiveness of managers and the presence of capable guardians. Crime pattern theory links places with desirable targets and the context within which they are found by focusing on how places come to the attention of potential offenders. It is worth noting that although crime displacement theory, crime pattern theory and routine activity theory are mutually supportive in many aspects, yet giving different explanations of crime at specific locations. A crime pattern theorist would focus on how offenders discover and gain access to the place as for a given set of high-crime locations. A routine activity theorist would focus instead on the behaviors of the targets and the possible absence of controllers whose presence could have prevented the offenses from taking place-guardians, handlers, and place managers.

\section{Conclusion}

Crime displacement theory looks at the possibility of crime being shifted or displaced to other location. In other words, places are problematic because of their location and relationship to the environment for the crime pattern theorist. As for the routine activity theorist, places are problematic due to the absence and presence of the types of people at the location. On the other hand, for a crime displacement theorist, crime will be displaced. Clearly all the explanations can be valid in different contexts and situations. It is possible that crime-specific explanations may show that for some events crime pattern theory is a particularly useful explanation, for other events routine activity theory offers greater insights, and for still a third group of events some combination of the two theories is needed.

\section{References}

[1] Armitage, Rachel (1999). An evaluation of Secured by Design Housing Schemes throughout the West Yorkshire Area, The University of Huddersfield: The applied criminology group

[2] Barr, R. \& Pease, K. (1990). Crime Placement, Displacement and Deflection in Tonry, M. \& Morris, N. (Eds.) Crime and Justice: A Review of Research, 12, Chicago: University of Chicago Press

[3] Barr, R. \& Pease, K. (1992). A place for every crime in its place: An alternative perspective on crime displacement in Evans, D.J., Fyfe, N.R. \& Herbert, D.T. (Eds.). Crime, Policing and Place. Essays in Environmental Criminology, London, UK: Routledge

[4] Bodman, P. \& Maultby, C. (1997). Crime, punishment and deterrence in Australia, International Journal of Social Economics, 24, 884-901

[5] Braga, Anthony (2007). Effects of Hot Spots Policing on Crime, A Campbell Collaboration Systematic Review

[6] Braga, Anthony \& Brenda, J. Bond (2008). Policing crime and disorder hot Spots: A Randomized controlled trial, Criminology, 46, 577-607

[7] Barron, J.M. (1991). Repulsive and attractive displacement paper presented to the American Society of Criminology, San Francisco

[8] Brantingham, Patricia L., \& Paul J. Brantingham (1993). Nodes, paths and edges: Considerations on the complexity of crime and the physical environment. Environmental Psychology, 13, 3-28

[9] Brown, Jon (1999). An Evaluation of the Secured by Design Initiative in Gwent, South Wales, Unpublished Dissertation, University of Leicester

[10] Caulkins, J.P. (1992). Thinking about displacement in drug markets: Why observing change of Venue isn't enough? in Journal of Drug Issues

[11] Clarke, Ronald V. (1992). Situational Crime Prevention: Successful Case Studies. Albany, NY: Harrow and Heston

[12] Clarke, Ronald V. (1998). Situational Crime Prevention: Successful Case Studies (2 ${ }^{\text {nd }}$ ed.). Albany, NY: Harrow \& Heston

[13] Clarke, Ronald V. (1999). Hot products: Understanding, anticipating and reducing demand for stolen goods, Police Research Series Paper 112, London: Home Office Research, Development and Statistics Directorate 
[14] Clarke, Ronald.V. \& Homel, R. (1997). A Revised Classification of Situational Crime Prevention Techniques in Lab, S.P. (Ed.), Crime Prevention at a Crossroads, Cincinnati, $\mathrm{OH}$ : Anderson Publishing Co

[15] Clarke, Ronald V. \& Weisburd, D. (1994). Diffusion of crime control benefits in Crime Prevention Studies, ed. R.V. Clarke, 165-183. Monsey, NY: Criminal Justice Press

[16] Cohen, Lawrence E. \& Felson, Marcus (1979). Social change and crime rate trends: A Routine Activity Approach, American Sociological Review, 44, 588-608

[17] Cook, Philip J. \& MacDonald, John (2010). Mobilizing Private Inputs for Crime Prevention. This paper was prepared for the NBER Economical Crime Control Conference, held at UC Berkeley on January 15th and 16th, 2010

[18] Cornish, Derek B. (1994). The procedural analysis of offending and its relevance for situational prevention in Crime Prevention Studies, 3, Clarke, R.V. \& Monsey, (Eds.), New York, Criminal Justice Press

[19] Cornish, Derek B. \& Ronald V. Clarke (1986). In: D.B. Cornish and R.V. Clarke (Eds.). The Reasoning Criminal: Rational Choice Perspectives on Offending. New York: Springer-Verlag

[20] Cornish, Derek B. \& Ronald V. Clarke (1987). Understanding Crime Displacement: An Application of Rational Choice Theory, Criminology, 25(4), 933-947

[21] Cornish, Derek, B. \& Ronald V. Clarke (1990). Crime specialization in crime displacement and rational choice in Wegener, H. (Eds.). Criminal Behavior and the Justice System, New York: Springer-Verlag

[22] Cornish, Derek, B. \& Ronald V. Clarke (2003). Opportunities, precipitators and criminal decision in M. J. Smith \& D. B. Cornish (Eds.), Crime Prevention Studies, 16, 41-96, Monsey, NY: Criminal Justice Press

[23] Crawford, Adam (1998). Crime Prevention and Community Safety: Politics, policies and practice, London: Longman

[24] Dingle, J. (2005). Displacement Theory, Cargo Security International, 3(5)

[25] Eck, John E. (1993). The threat of crime displacement, Criminal Justice Abstracts, 25, 527-546

[26] Ekblom, P. (1989). Evaluation: The Management of Uncertainty, Paper presented at the British Criminology Conference

[27] Ekwall, Daniel (2009). The displacement effect in cargo theft, International Journal of Physical, Distribution \& Logistics Management, 39(1), 47-62

[28] Ekwall, Daniel \& Lumsden, K. (2007). Differences in stakeholder opinion regarding antagonistic gateways within the transport network, Proceedings of Nofoma, Reykjavik, Iceland

[29] Felson, Marcus (1994). A Crime Prevention Extension Service, Crime Prevention Studies, 3

[30] Felson, Marcus \& Clarke, Ronald V. (1998). Opportunity makes the thief: Practical theory for crime prevention, Police Research Series Paper 98; London: Home Office Research, Development and Statistics Directorate
[31] Gabor, Thomas (1981). The crime displacement hypothesis: An empirical examination. Crime and delinquency, 26, 390404

[32] Gabor, Thomas (1990). Crime displacement and situational prevention: Towards the development of some principles, Canadian Journal of Criminology, 32, 41-74

[33] Gary Kleck \& Don Kates (2001). Armed: New Perspectives on Guns, Amherst, NY: Prometheus Books

[34] Guerette, Rob, T. \& Bowers, K.J. (2009). Assessing the extent of crime displacement and diffusion of benefits: A review of situational crime prevention evaluations, Criminology, 47(4), $1331-1368$

[35] Guerette, Rob T., Vanja Stenius \& Jean, McGloin (2005). Understanding offending specialization and versatility: A reapplication of the rational choice perspective, Journal of Criminal Justice, 33(1), 77-87

[36] Hesseling, B.P. (1994). Displacement: A review of the empirical literature, Clarke, R. (Ed.), Crime Prevention Studies, 3, 197230, Monsey, New York: Criminal Justice Press

[37] Hill, I. \& Pease, K. (2001). The wicked issues: Displacement and sustainability in secure foundations: Key issues in crime prevention, Crime reduction and community safety, $\mathrm{S}$. Ballantyne, Pease, K. \& McLaren, V. (Eds.), London: IPPR

[38] Klaus van Lampe (2011). Re-Conceptualizing transnational organized crime: Offenders as problem solvers, International Journal of Security and Terrorism, 2, 1- 23

[39] Lab, S.P. (2000). Crime prevention: Approaches, practices and evaluations ( $4^{\text {th }}$ ed.). Cincinnati, $\mathrm{OH}$ : Anderson, Publishing, Co

[40] Mayhew, P (1988). The British Gas Suicide Story and Its Criminological Implications. In: M. Tonry and N. Morris (Eds.), Crime and Justice: A Review of Research, 10, Chicago, IL: University of Chicago Press

[41] McLennan, David \& Adam, Whitworth (2008). Displacement of Crime or Diffusion of Benefit: Evidence from the New Deal for Communities Programme. Social Disadvantage Research Centre, University of Oxford, Communities and Local Government

[42] Miethe, T. (1991). Citizen-Based Crime Control Activity and Victimization Risks: An Examination of Displacement and the Free-Rider Effect, Criminology, 29, 419-441

[43] Moss, K. \& Pease, K. (1999). Crime and Disorder Act 1998: Section 17, A Wolf in Sheep's Clothing, Crime Prevention and Community Safety: An International Journal, 1-19, Leicester: Perpetuity Press

[44] Parker, R. \& Nash (1995). Bringing Booze' back in the relationship between alcohol and homicide, Journal of Research in Crime and Delinquency, 32, 3-38

[45] Pascoe, Tim (1999). Evaluation of Secured by Design in Public Sector Housing, Building Research Establishment

[46] Rengert, George F. (1989). Spatial justice and criminal victimization, Justice Quarterly, 6, 543-564

[47] Rengert, George F. (1990). Drug purchasing as a routine activity of drug dependent property Criminal and the spatial concentration of crime, Paper presented at the American Society of Criminology Annual Conference, USA 
[48] Reppetto, Thomas A. (1974). Residential Crime, Cambridge, MA: Ballinger

[49] Roman, C.G., Meagon C., Mark C., Erica L. \& Shannon C. (2005). The weed and seed initiative and crime displacement in South Florida: An examination of spatial displacement associated with crime control initiatives and the redevelopment of public housing. Final Report, the Urban Institute

[50] Sherman, Lawrence W. (1990). Police crackdowns: Initial and residual deterrence in Tonry, M. \& Norval, M. (Eds.) Crime and Justice: A Review of Research, 12, Chicago: University of Chicago Press

[51] Sherman, Lawrence W., Patrick R. Gartin \& Michael E.
Buerger (1989). Hot Spots of Predatory Crime: Routine Activities and the Criminology of Place, Criminology 27(1), 27-56. DOI: $10.1111 /$ j.1745-9125.1989.tb00862.x

[52] Teresa, L. (1999). The impact of neighborhoods, schools, and malls on the spatial distribution of property damage, Journal of Research in Crime and Delinquency, 36, 393-422

[53] Town, Stephen (2001). Crime Displacement, the Perception, Problems, Evidence and Supporting Theory, Bradford District Architectural Liaison Officer, Bradford

[54] Weisburd, D., Laura W., Justin R., Eck, J. Joshua C. Hinkle \& Frank G. (2006). Does crime just move around the corner? A controlled study of spatial displacement and diffusion of crime control benefits, Criminology, 44(3), 549-591 